Check for updates

Cite this: RSC Adv., 2017, 7, 56328

\title{
Construction of core-shell hybrid nanoparticles templated by virus-like particles $\uparrow$
}

\author{
A. Liu, ${ }^{a}$ L. Yang, (DD a M. Verwegen, ${ }^{a}$ D. Reardon ${ }^{b}$ and J. J. L. M. Cornelissen (D) *a
}

Plant viruses have been widely used as templates for the synthesis of organic-inorganic hybrids. However, the fine-tuning of hybrid nanoparticle structures, especially the control of inorganic particle size as well as where the silication occurs (i.e. outside and/or inside of the capsid), by simply tuning the $\mathrm{pH}$ remains a challenge. By taking advantage of the templating effect of Cowpea Chlorotic Mottle Virus (CCMV) protein cages, we show that the silication at the exterior or interior surface of protein capsids, as well as the resulting structures of silica/virus hybrid nanoparticles can be fine-tuned by $\mathrm{pH}$. At pH 4.0, only small

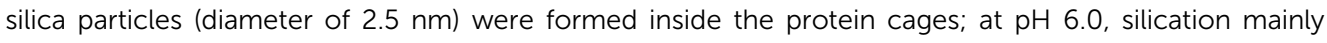
takes place inside of the protein cages, leading to monodisperse silica nanoparticles with diameters of $14 \mathrm{~nm}$; and at $\mathrm{pH} 7.5$, silica deposition takes place both at the interior and exterior surfaces of protein cages in aqueous conditions. Under these reaction conditions, multiple component hybrid virus/ nanoparticulate systems, such as CCMVAu/silica and Au/silica nanoparticles were prepared step-by-step. Upon removal of the CCMV template by thermal degradation a single gold nanoparticle can be encapsulated in a hollow silica shell emulating the structure of a baby's rattle with an unattached solid particle within a hollow particle. The Au/silica core-hollow shell nanoparticles can then be further used as a stable catalyst. It is anticipated that these synthetic methods provide a versatile methodology to prepare core-shell nanomaterials with well-designed structure and functionality.

Received 13th October 2017

Accepted 5th December 2017

DOI: 10.1039/c7ra11310b

rsc.li/rsc-advances was hard to control due to particle cross-linking of silanol groups. By mimicking natural silica growth, positively charged APTES ((3-aminopropyl)triethoxysilane) was pre-adsorbed onto the negatively charged viral NPs surface and hydrolyzed/ condensed to form silica nuclei, then TEOS (tetraethoxysilane) was added to promote the growth of the silica shell. ${ }^{49,51}$ Silication on tube-like virus particles, such as the tobacco mosaic virus (TMV) was also reported. ${ }^{44,47}$ In this case, the modification of the outer-surface of the virus particles with a polymer is necessary, in order to obtain silica shells with sufficient thickness to tolerate the deposition of metal nanoparticles. ${ }^{44,45}$

Although the construction of silica-virus hybrid NPs was successful, the fine-tuning of hybrid NP structures, especially the control of silication outside or inside the virus capsid, remains challenging. When the exterior surface of the capsid is negatively charged it can interact with positively charged silica precursors, for example APTES, and thus facilitate the deposition of silica on the exterior surface of capsid. Meanwhile, the porous structure of the protein shell of virus NPs allows foreign molecules, such as the silica precursors/or silica nuclei, to get access inside the virus cage. In view of these considerations, virus silication can not only take place at the exterior surface but also inside the capsid, leading to structurally diverse hybrid NPs. ${ }^{52}$ As a representative model system, the Cowpea Chlorotic Mottle Virus (CCMV) consists of 180 protein units, which assemble into a porous capsid shell with single-stranded RNA
${ }^{a}$ Laboratory for Biomolecular Nanotechnology (BNT), MESA+ Institute of Nanotechnology, University of Twente, 7500 AE Enschede, The Netherlands. E-mail: J.J.L.M.Cornelissen@utwente.nl

${ }^{b}$ DSM Materials Science Center, B. V., P. O. Box 18, 6160 MD Geleen, The Netherlands $\dagger$ Electronic supplementary information (ESI) available. See DOI: 10.1039/c7ra11310b 
encapsulated. ${ }^{\mathbf{4 0 - 4 3 , 5 3 , 5 4}}$ The interaction between negatively charged CCMV capsid ( $\mathrm{pI}=3.8$ ) and APTES can be controlled by $\mathrm{pH}$, due to the $\mathrm{pH}$ dependence of the negative charge density of the exterior capsid surface. ${ }^{52,55,56}$ Meanwhile, the size of CCMV capsid pores (1-2 nm) is close to silica nuclei $(1-2 \mathrm{~nm})^{57,58}$ and is also $\mathrm{pH}$ dependent, which allows the control of accessibility of silica nuclei through the capsid by $\mathrm{pH}$. CCMV NPs are stable at a $\mathrm{pH}$ range of 3.0 to 6.0 , where the pore size of the capsid is about $1 \mathrm{~nm}$ in diameter. The capsid starts to swell at $\mathrm{pH} \geq 6.0$, at which the pore size increases to $2 \mathrm{~nm}$, resulting in higher accessibility for foreign molecules. ${ }^{59,60}$ Synthesis of monodisperse inorganic nanoparticles at this $\mathrm{pH}$ has been widely reported. ${ }^{61-63}$ The virus NPs are highly swollen when the $\mathrm{pH}>$ 7.5 while the virus disassembles at this $\mathrm{pH}$ with high salt concentrations. ${ }^{64}$ For the accessibility of the CCMV protein cage three stages were recognized: $\mathrm{pH}<5.5$, low accessibility; $\mathrm{pH}$ 5.57 , medium accessibility; $\mathrm{pH} \geq 7.5$, high accessibility. ${ }^{65}$ Therefore, it should be possible to control the deposition of silica in the cavity to control the growth of particle size as well as control the deposition on both sides of the capsid surface by tuning the $\mathrm{pH}$ of the solution, resulting in hybrid protein-silica nanoparticles with controlled structure.

To confirm our hypothesis, CCMV NPs were used as a template to construct hybrid nanoparticles under three representative $\mathrm{pH}$ conditions, i.e.: $\mathrm{pH} 4.0,6.0$ and 7.5. The silication at different $\mathrm{pH}$ conditions as well as the structures of the formed hybrid nanoparticles were studied. The control of silication was further employed to construct multi-component core-shell nanoparticles, with as a proof of concept, hybrid nanoparticles with core-shell structures including a Au NPs encapsulating hybrid NP (CCMVAu), which was subsequently silicated to form multi-shell hybrid NPs (CCMVAu/silica). Finally after removal of the organic CCMV template by a thermal calcination process, a solid Au nanoparticle-hollow silica NPs (Au/silica) rattle structure was obtained. The catalytic activity of Au NPs combined with the stability of silica shell, enabled the formation of highly stable catalytic materials. ${ }^{66}$

\section{Results and discussion}

To prepare virus/silica hybrid NPs, silication was carried out by treating CCMV with APTES, followed by TEOS, at different pHs. The reaction solutions were incubated while rotating for 3 days at room temperature, washed with buffer solution for 3 days, followed by washing with MilliQ 18 Mohm water another 3 days. Silication and purification of gold containing protein cages was carried out in via similar method. The silication of virus particles was first confirmed by energy dispersive X-ray spectroscopy (EDX), which shows a silicon signal for all samples (Fig. 1).

Transmission Electron Microscopy (TEM) characterization further confirmed the successful silication of CCMV. Analysis of stained TEM images with negatively stained CCMV-silica4 displayed NP with $D=22 \mathrm{~nm}$ in with a dark core of $D=15 \mathrm{~nm}$ (Fig. 2b), while non-stained CCMV-silica4 NPs were hardly visible in TEM (data not shown), indicating a low density silica on the virus particles which was also confirmed by EDX elemental mapping (Fig. S1 $\dagger$ ). Stained CCMV-silica6 showed $D=24 \mathrm{~nm}$ in
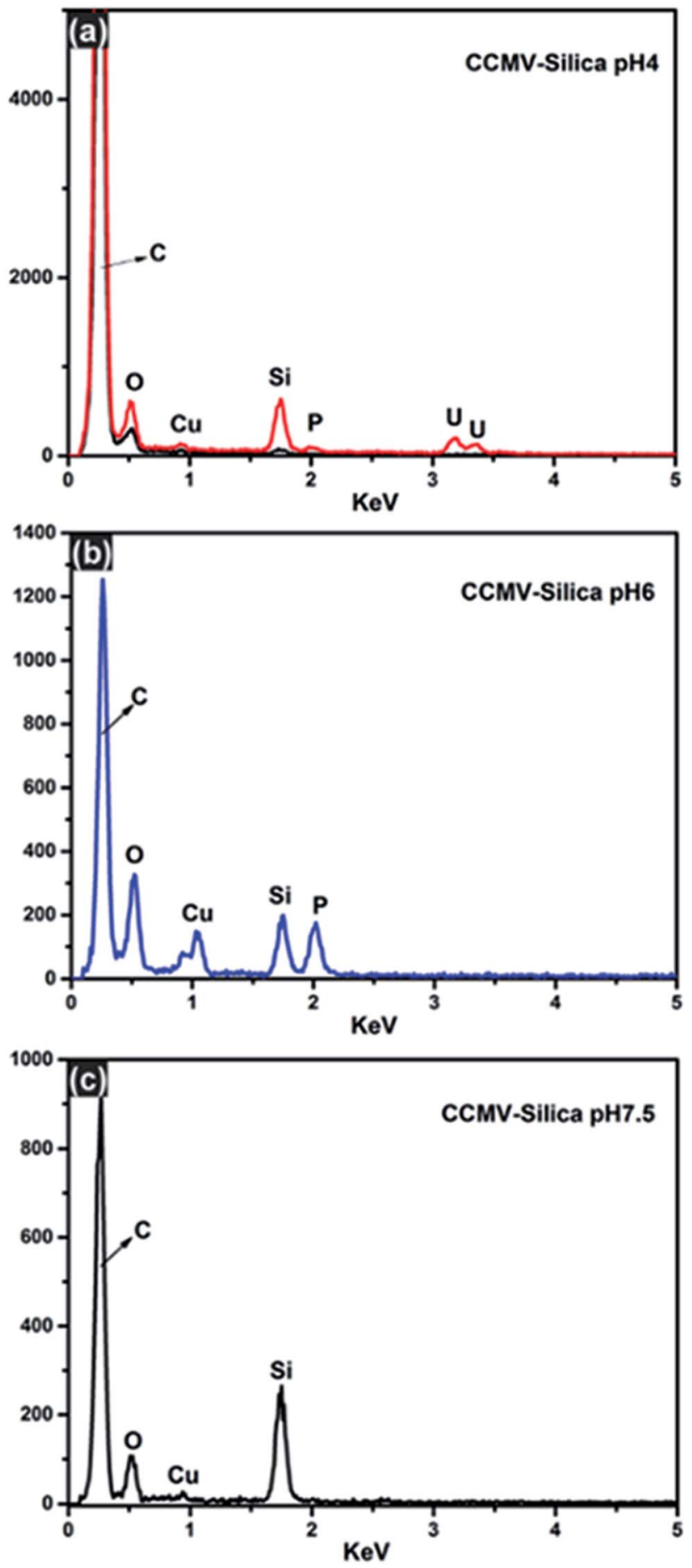

Fig. 1 EDX analysis of CCMV templated silication at (a) pH 4.0 (CCMVsilica4), (b) pH 6.0 (CCMV-silica6), and (c) pH 7.5 (CCMV-silica7.5).

NPs (Fig. 2c), while non-stained CCMV-silica6 NPs showed a much smaller particle size with $D=14 \mathrm{~nm}$ (Fig. 2d). Protein shells are hardly visible under TEM without proper staining, but silica, which has a higher contrast than the organic protein shell, can be observed. Therefore, these $14 \mathrm{~nm}$ sized NPs from nonstained CCMV-silica6 are identified as silica particles, indicating that the silication mainly occurred inside of the virus cage 

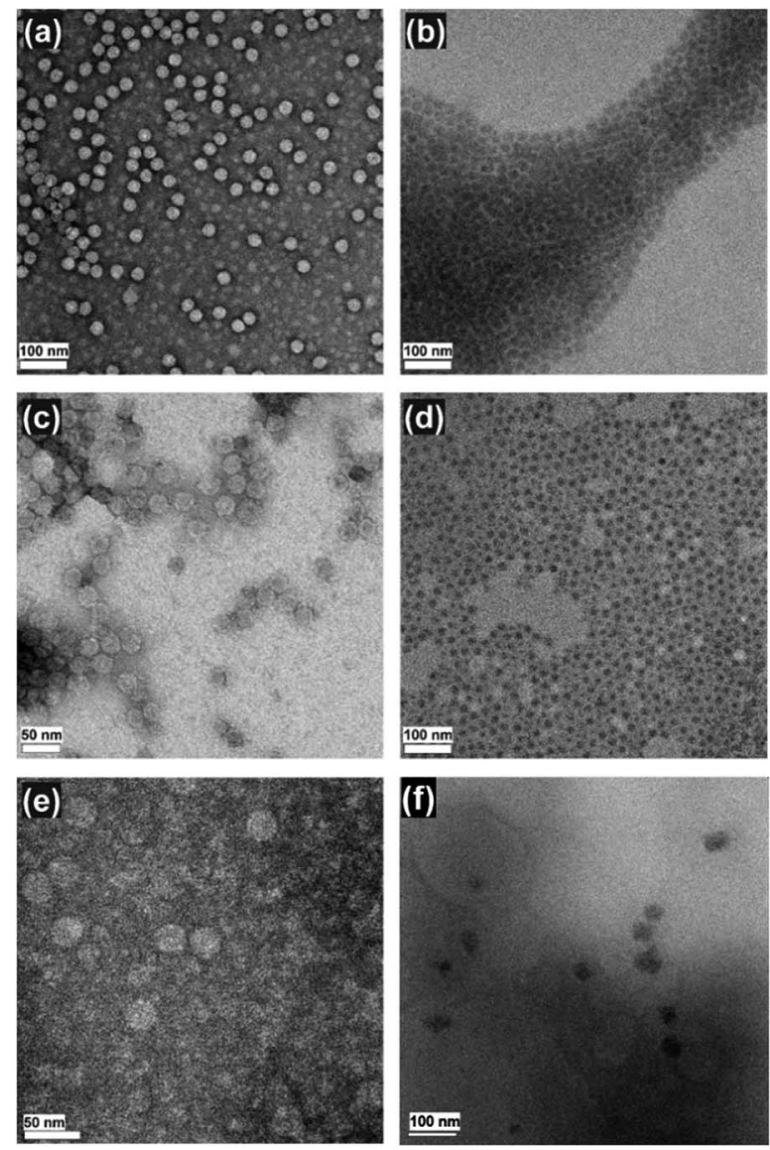

Fig. 2 TEM images of (a) native CCMV, with staining; (b) CCMV-silica4 with staining; (c) and (d) CCMV-silica6 with staining and without staining, respectively; (e) and (f) CCMV-silica7.5 with staining and without staining, respectively.

at $\mathrm{pH}$ 6.0. Further evidence to support this conclusion is that nanoparticles with a size of $D=14 \mathrm{~nm}$ were retained after calcination (Fig. S2 $\dagger$ ). For CCMV-silica7.5, the stained sample showed particles with $D=27 \mathrm{~nm}$ (Fig. 2e), while the non-stained sample showed particles with average $D=30 \mathrm{~nm}$ (Fig. 2f), suggesting silication might have taken place not only inside the protein cage, but also at the exterior surface of capsid or at the interface of the coat proteins. Although some smaller particles with $D=18 \mathrm{~nm}$ were also observed which may mainly have silication inside protein cages. Particle sizes analysed by dynamic light scattering (DLS) are consistent with TEM analysis. Both CCMV-silica4 and CCMV-silica6 show average particle sizes around $D=25 \mathrm{~nm}$ with narrow distributions. For CCMV-silica7.5 particles, a relative broader peak with an average diameter of $D=$ $30 \mathrm{~nm}$ was found in the DLS analysis (Fig. S3†).

The structures of silicated NPs were further studied by sodium dodecyl sulfate polyacrylamide gel electrophoresis (SDS-PAGE) analysis, which shows CCMV protein bands at 20 kDa for CCMV-silica4 and CCMV-silica6 (Fig. S4 $\dagger$ ). ${ }^{23}$ The presence of these CCMV protein bands indicates that proteins were denatured and separated without the protection of silica shell. For CCMV-silica7.5, however, no significant protein band at 20 $\mathrm{kDa}$ was observed, instead aggregates remained on top of the stacking gel (Fig. S4, $\uparrow$ line 4), suggesting a robust silica shell that prevents proteins from being released. This increased silica precipitation on the exterior surface could be ascribed to a higher electrostatic interaction between the capsid and APTES at a higher $\mathrm{pH}$.

Removal of the protein part by calcination resulted in silica nanoparticles with height of $2.5 \mathrm{~nm}, 14 \mathrm{~nm}$ and $20 \mathrm{~nm}$ from CCMV-silica4, CCMV-silica6 and CCMV-silica7.5 respectively as observed by Atomic Force Microscopy (AFM), as shown in Fig. 3. For CCMV-silica4 and CCMV-silica6, the obtained silica nanoparticles were almost homogeneous in size from AFM images, suggesting a well-controlled silication in the confined viral cavity.

The formation of diverse structures of silicated nanoparticles formed at different $\mathrm{pH}$ values in the presence of CCMV is attributed to the $\mathrm{pH}$ dependence of pore size and charge state of the exterior virus surface. Three stage were recognized for the accessibility of the CCMV protein cage: $\mathrm{pH}<5.5$, low accessibility; $\mathrm{pH}$ 5.5-7, medium; $\mathrm{pH} \geq 7.5$, high accessibility. ${ }^{65}$ Therefore, the access of silica nuclei into the protein cages can presumably be controlled by varying the $\mathrm{pH}$ of the system. Moreover, the electrostatic interaction between the negatively charged exterior of the protein shell and the positively charged APTES induces the silication on the exterior surface of the capsids. The exterior surface of capsids becomes more negatively charged when the $\mathrm{pH}$ is increased, since the $\mathrm{p} K_{\mathrm{a}}$ of CCMV is $3.8 .^{67}$ Combination of these two factors leads to a competition of silica layer growth between the interior and exterior of the protein cages, resulting in silicated virus particles with a finetuned core-shell structures.

To construct multifunctional hybrid NPs, we employed the above procedure at neutral or slightly alkaline $\mathrm{pH}$ to gold nanoparticles in CCMV capsids (CCMVAu) yielding CCMVAu/silica, and $\mathrm{Au}$ /silica materials after removal of protein component.

Commercial $\mathrm{Au}$ NPs with diameter of $7 \mathrm{~nm}$ stabilized by tannic acid were encapsulated in the protein capsid as previously reported. ${ }^{68}$ The assembly resulted in hybrid CCMVAu NPs with a core-shell structure with average size of $18 \mathrm{~nm}$, in combination with capsids containing only tannic acid (Fig. 4a). Silication of CCMVAu resulted in CCMVAu/silica multiple coreshell materials (Fig. 4b). According to TEM images, the average diameter of CCMVAu/silica was found around $D=28 \mathrm{~nm}$ with a thickness of the silica shell of $5 \mathrm{~nm}$ (Fig. S5 $\dagger$ ). In this step, additional tannic acid was added to the CCMVAu solution, the mixed solution was incubated on a rotor for $0.5 \mathrm{~h}$, silica precursor was then added to produce CCMVAu/silica hybrid NPs. Tannic acid contains a large number of phenol groups which can easily combine with carboxyl groups on the exterior surface of capsid through hydrogen bonding. ${ }^{\mathbf{6 9 , 7 0}}$ Moreover, tannic acid has been widely used as a template for silica growth. ${ }^{71,72}$ Therefore, the extra tannic acid in this case can absorb on the exterior surface of capsids and act as a guiding reagent, resulted in uniform silica coatings on protein capsids, as shown in Fig. 4b. Elemental mapping showed a thin layer of silica formed around the capsid layer, a minimal amount of silica was found at the interface of the capsid, and no silica was found in the core of the particles (Fig. S6†). Silication in the absence of tannic acid only resulted in irregular NPs (Fig. S7†), 

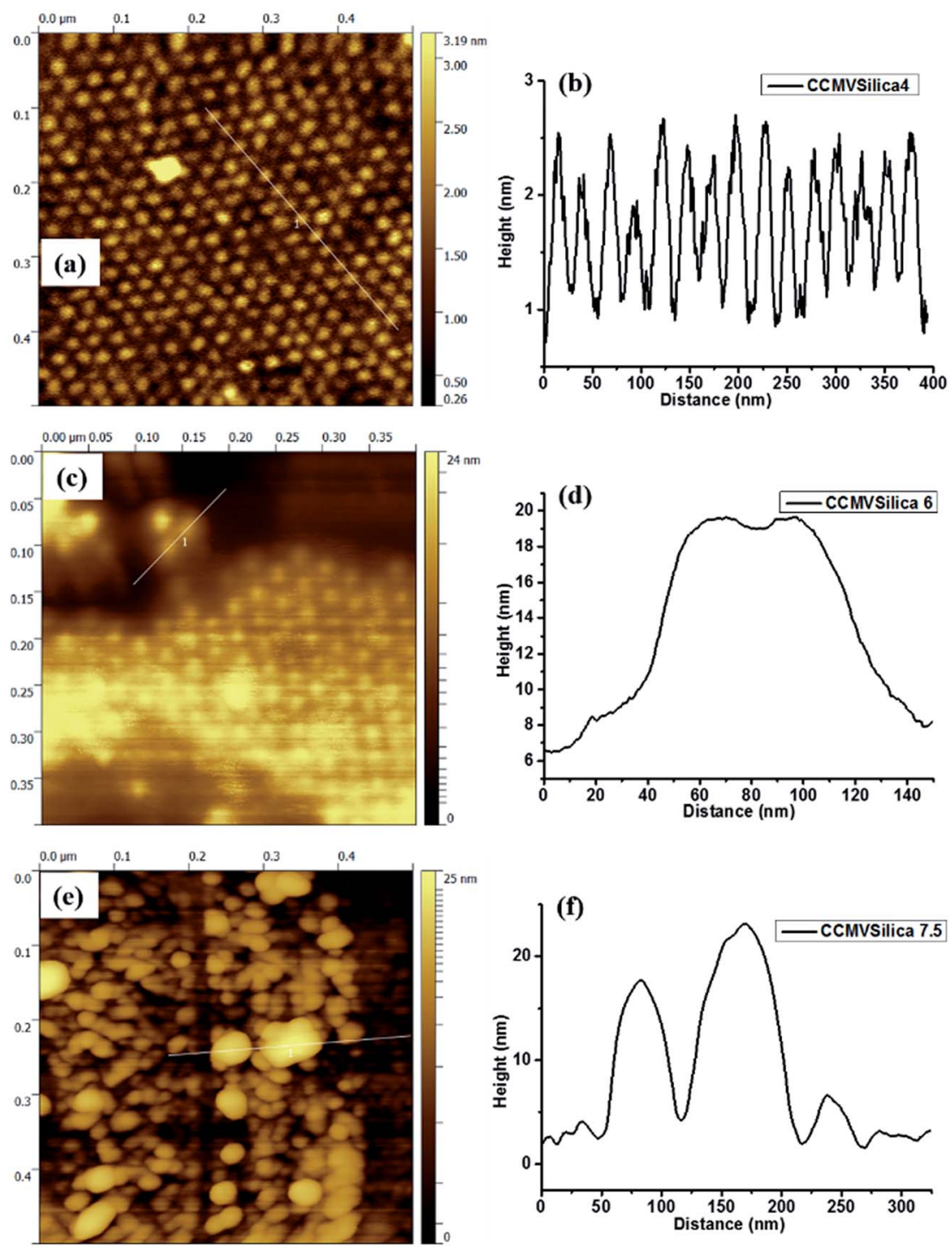

Fig. 3 AFM image of CCMV-silica after calcination (a) CCMV-silica4, (b) height profile of AFM image (a); (c) CCMV-silica6, (d) height profile of AFM image (c); and (e) CCMV-silica7.5, (f) height profile of AFM image (e).
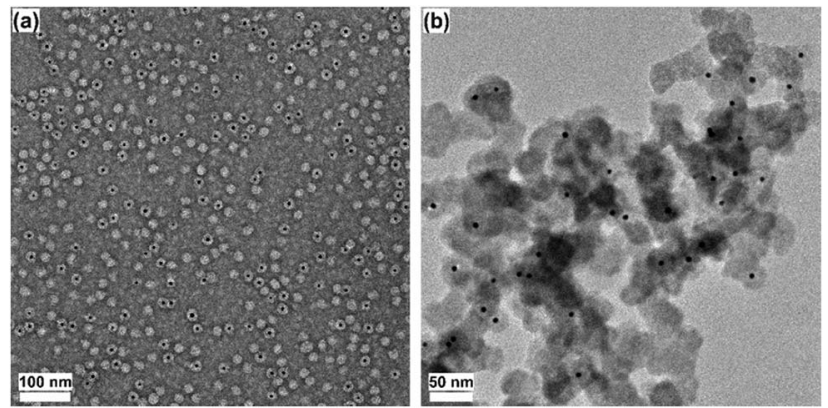

Fig. 4 TEM images of (a) gold NPs encapsulated inside the CCMV protein cage (CCMVAu) with staining; (b) silicified CCMVAu shows Au core/capsid/silica double shell hybrid structures (CCMVAu/silica).

indicating that tannic acid plays an essential role in directing silica growth on the exterior surface of CCMV capsids in aqueous solution.
Calcination of CCMVAu/silica resulted in Au/silica core-shell NPs, as the organic components were removed by heating at $550{ }^{\circ} \mathrm{C}$ for $3 \mathrm{~h}$. The obtained Au/silica materials were characterized by STEM (Fig. 5a and b), showing the core-shell structure. The core particles with a higher contrast correspond to AuNPs, while the shell consists of silica. No individual AuNPs nor aggregates were observed by STEM analysis, suggesting that the protein cage induced silica shell acts as a protecting layer to prevent aggregation during the calcination at high temperature.

The removal of the vaporized organic materials from the silica network, suggests that these are sufficiently porous to allow small molecules to reach the gold core. This prompted us to study the catalytic activity of the encapsulated Au NPs to explore their potential application as nanoreactors. ${ }^{73-75}$ As a typical example, the reduction of 4-nitrophenol (4NP) was catalyzed by $\mathrm{Au} /$ silica and the progress of the reactions was monitored by UV-vis spectroscopy (Fig. 5c). The characteristic 

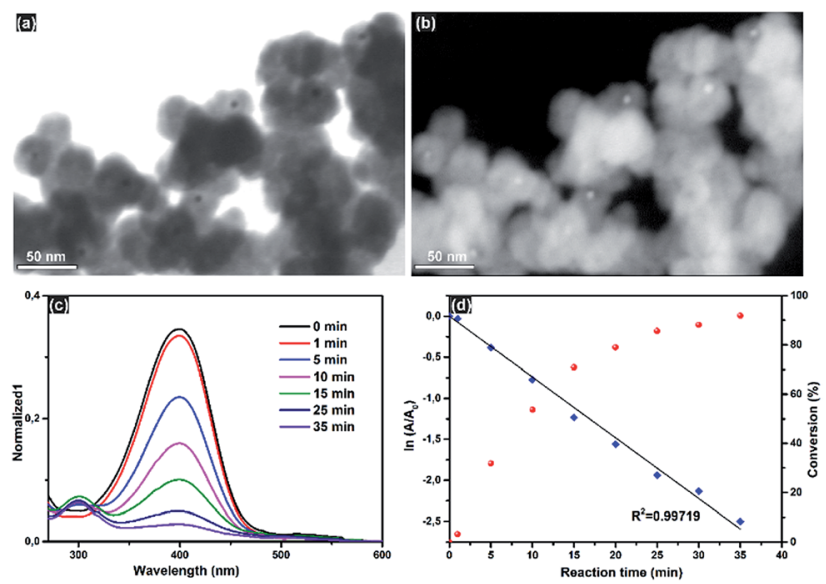

Fig. 5 (a) Bright field and (b) dark field STEM images of Au/silica coreshell materials. (c) UV-vis spectra the catalytic reduction of 4-NP by $\mathrm{Au} /$ silica monitored in time and $(\mathrm{d})$ reduction rate $\ln \left(A / A_{0}\right)$ (blue dots) and conversion (red dots) versus reaction time.

absorption band of deprotonated $4 \mathrm{NP}$ at $\lambda=400 \mathrm{~nm}$ decreased, while a new absorption band at $\lambda=300 \mathrm{~nm}$ - indicating the formation of aminophenol - appears during the reaction. The correlation of $\ln \left(A / A_{0}\right)$ versus reaction time (Fig. $5 \mathrm{~d}$ ) points to pseudo-first-order kinetics with a rate constant of $1.23 \times 10^{-3}$ $\mathrm{s}^{-1}$ that is comparable to previous studies. ${ }^{76,77}$ Under the protection of porous silica shell, Au NPs are well stabilized without aggregation, while Au NPs that are stabilized only by tannic acid tend to aggregate after reaction. ${ }^{26}$ Furthermore, it's facile to coat silica shell protected Au NPs on substrates to prepare easy to handle catalytic thin films, which is a challenge for naked gold nanoparticles.

\section{Conclusions}

Core-shell structures of silica and virus based materials can be constructed by controlling the $\mathrm{pH}$ during the silication process. We have confirmed that at $\mathrm{pH}=6$ silica preferable forms on the inside of the CCMV virus, while at $\mathrm{pH}=7.5$, a silica shell surrounding the protein cage is observed. By further reducing the $\mathrm{pH}$ the penetration of silica precursors is virtually blocked, so only small particles $(D<3 \mathrm{~nm})$ are observed. This empirical control over the silica formation with the virus as a template allowed us the construct hybrid silica/gold materials, based on gold nanoparticles encased in the CCMV protein cage devoid of the genetic material. The resultant Au/protein shell/silica materials could be transformed to gold inside silica core-shell networks that are catalytically active in the reduction of 4nitrophenol as an example. Considering the diversity of virus (-like) particles nowadays studied in materials science and their potential cargos, ${ }^{78-80}$ this methodology is not only limited to the specific $\mathrm{Au} /$ silica system, but also applicable for the preparation of a series of core-shell nanomaterials. It is anticipated that in that way it paves the way for preparing core-shell hybrid NPs with well-designed structures, towards advanced applications in catalysis, drug delivery, bio-sensor and bio-imaging.

\section{Experimental}

\section{Chemicals}

All chemicals were of analytical quality, and used as purchased without further purification. Ethanol, (3-aminopropyl)triethoxysilane (APTES), and tetraorthosilicate (TEOS), were all purchased from Sigma-Aldrich. Buffers were prepared with ultrapure water (Milli Q $18 \mathrm{MOhm}$ water). CCMV NPs were isolated from infected cowpea plant and stored in virus buffer solution under $4{ }^{\circ} \mathrm{C} .{ }^{13}$

\section{Synthetic procedures}

Preparation of silica/virus hybrid NPs: native CCMV $\left(4 \mathrm{mg} \mathrm{mL}^{-1}\right)$ in $10 \mathrm{mM}$ sodium phosphate (PB) buffer of pH 6 was treated with TEOS and APTES (90: $10 \mathrm{~mol} \%$ ) ethanol solution with final silica concentration of $0.08 \mathrm{wt} \%$, and left on the rotator for 3 days at room temperature. Considering the limited stability of virus nanoparticles in organic solvent, the final ethanol concentration in water was controlled at $9 \%$. The reaction solution was then dialyzed against buffer for 3 days (refresh buffer 3 times per day), additionally dialyzed against Milli-Q (MQ $18 \mathrm{Mohm}$ ) for another 3 days to completely remove the non-reacted silane and salt. The silicified CCMV nanoparticles were separated from nontemplated silica by centrifugation at $10 \mathrm{k} \mathrm{rpm}$ for $10 \mathrm{~min}$, and the supernatant was collected and named as CCMV-silica6. Samples under $\mathrm{pH} 4$ of $10 \mathrm{mM}$ sodium acetate buffer and $\mathrm{pH}$ 7.5, $10 \mathrm{mM}$ Tris-HCl buffer were prepared in the same way, and were named as CCMV-silica4 and CCMV-silica7.5, respectively.

Preparation of gold encapsulated CCMV NPs and silication: encapsulation of gold NPs into CCMV protein cages was carried out according to references, ${ }^{26}$ hybrid NPs were named as CCMVAu. Then gold core-protein-silica-double shell hybrid nanoparticles (CCMVAu/silica) were prepared and templated by CCMVAu NPs. In detail, CCMVAu NPs were washed against MQ water with centrifuge filter for three times to completely remove salt, then a certain amount of tannic acid was added into the solution, the mixture was left on the rotor for $0.5 \mathrm{~h}$ (silication without tannic acid was also conducted). Further silication method is same as the preparation of silica/virus hybrid NPs. CCMVAu/silica without tannic acid as directing agent was prepared in a similar method.

Catalytic activity of Au/silica: drop $100 \mu \mathrm{L}$ CCMVAu/silica solution (contain $0.0127 \mathrm{mg} \mathrm{mL}^{-1}$ of Au NPs) on silicon wafer and dried under vacuum, calcination was then performed to form Au/silica NPs. This substrate was then used for catalytic reaction by mixing with $510 \mu \mathrm{L}$ of Milli-Q water, $90 \mu \mathrm{L}$ of $2 \mathrm{mM}$ of $4 \mathrm{NP}$ and $450 \mu \mathrm{L}$ of sodium borohydride. UV-vis monitor was started immediately after mixing.

\section{Characterization}

Poly Acrylamide Gel Electrophoresis (PAGE) was performed in the presence of sodium dodecyl sulfate (SDS). Samples were heated at $99{ }^{\circ} \mathrm{C}$ for $10 \mathrm{~min}$ in the presence of 2-mercaptoethanol and $1 \%$ SDS.

Transmission electron microscopy (TEM) analysis was performed using Philips CM300 microscope. Samples for imaging 
were deposited onto a 200 mesh copper grid and left for $2 \mathrm{~min}$, after which the excess buffer or water was blotted away with filter paper. Samples were negatively stained by applying $5 \mu \mathrm{L}$ of stain (1\% w/v uranyl acetate in Milli Q water) onto the grid for $30 \mathrm{~s}$ and the excess water was blotted away with filter paper as well. Samples were dried overnight before imaging. Samples without staining were prepared in a similar way.

Dynamic light scattering (DLS) analysis was performed with Nanotrac by Anaspec operating with a Microtrac FLEX operating software at $25{ }^{\circ} \mathrm{C}$, using a laser wavelength of $780 \mathrm{~nm}$ at a scattering angle of $180^{\circ}$. The observed sizes and standard derivations of the nanoparticles were calculated by taking an average of 5 measurements.

Scanning transmission electron microscopy (STEM) analysis was taken with a Carl-Zeiss 1550 Gemini field emission scanning electron microscope. Samples were prepared in the same way as for TEM analysis.

Atomic Force Microscopy (AFM) measurements were performed using a Multimode AFM (Bruker Nano Surfaces, Santa Barbara, CA, USA) with a NanoScope V controller with tapping mode.

Muffle furnace calcination of particles were carried out with increasing temperature of $2{ }^{\circ} \mathrm{C} \min ^{-1}$, hold at $550{ }^{\circ} \mathrm{C}$ for $3 \mathrm{~h}$. Samples were drop-casted on the silicon wafers which were precleaned with oxygen plasma and dried overnight in the vacuum oven before calcination.

\section{Conflicts of interest}

There are no conflicts to declare.

\section{Acknowledgements}

This research forms part of the research program of the Dutch Polymer Institute (DPI), Project \#777t (DPI, P. O. Box 902, 5600 AX Eindhoven, the Netherlands) and the European Research Council is acknowledged for financial support by the grant ProtCage (616907).

\section{Notes and references}

1 J. N. Culver, A. D. Brown, F. Zang, M. Gnerlich, K. Gerasopoulos and R. Ghodssi, Virology, 2015, 479, 200-212.

2 Y. Liu, Y. Xu, Y. Zhu, J. N. Culver, C. A. Lundgren, K. Xu and C. Wang, ACS Nano, 2013, 7, 3627-3634.

3 X. Chen, K. Gerasopoulos, J. Guo, A. Brown, C. Wang, R. Ghodssi and J. N. Culver, ACS Nano, 2010, 4, 5366-5372.

$4 \mathrm{~K}$. Zhou, F. Li, G. Dai, C. Meng and Q. Wang, Biomacromolecules, 2013, 14, 2593-2600.

5 Y. Liu, W. Zhang, Y. Zhu, Y. Luo, Y. Xu, A. Brown, J. N. Culver, C. A. Lundgren, K. Xu, Y. Wang and C. Wang, Nano Lett., 2013, 13, 293-300.

6 C.-Y. Chiang, J. Epstein, A. Brown, J. N. Munday, J. N. Culver and S. Ehrman, Nano Lett., 2012, 12, 6005-6011.

7 D. Fernandes, M. J. Krysmann and A. Kelarakis, Chem. Commun., 2016, 52, 8294-8296.
8 E. Ertem, N. Murillo-Cremaes, R. P. Carney, A. Laromaine, E.-R. Janecek, A. Roig and F. Stellacci, Chem. Commun., 2016, 52, 5573-5576.

9 D. P. Cormode, P. A. Jarzyna, W. J. M. Mulder and Z. A. Fayad, Adv. Drug Delivery Rev., 2010, 62, 329-338.

10 S. W. Lee, S. K. Lee and A. M. Belcher, Adv. Mater., 2003, 15, 689-692.

11 P.-Y. Chen, X. Dang, M. T. Klug, J. Qi, N.-M. Dorval Courchesne, F. J. Burpo, N. Fang, P. T. Hammond and A. M. Belcher, ACS Nano, 2013, 7, 6563-6574.

12 A. Cumbo, B. Lorber, P. F. X. Corvini, W. Meier and P. Shahgaldian, Nat. Commun., 2013, 4, 1503.

13 A. R. Parker and H. E. Townley, Nat. Nanotechnol., 2007, 2, 347-353.

14 G. G. Daaboul, C. A. Lopez, J. Chinnala, B. B. Goldberg, J. H. Connor and M. S. Ünlü, ACS Nano, 2014, 8, 60476055.

15 R. J. Tseng, C. Tsai, L. Ma, J. Ouyang, C. S. Ozkan and Y. Yang, Nat. Nanotechnol., 2006, 1, 72-77.

16 S. Kanbak-Aksu, M. Nahid Hasan, W. R. Hagen, F. Hollmann, D. Sordi, R. A. Sheldon and I. W. C. E. Arends, Chem. Commun., 2012, 48, 5745-5747.

17 Y. Shin, A. Dohnalkova and Y. Lin, J. Phys. Chem. C, 2010, 114, 5985-5989.

18 T. Ueno, M. Suzuki, T. Goto, T. Matsumoto, K. Nagayama and Y. Watanabe, Angew. Chem., Int. Ed., 2004, 43, 25272530.

19 M. Suzuki, M. Abe, T. Ueno, S. Abe, T. Goto, Y. Toda, T. Akita, Y. Yamada and Y. Watanabe, Chem. Commun., 2009, 48714873, DOI: 10.1039/b908742g.

20 J. M. Slocik, R. R. Naik, M. O. Stone and D. W. Wright, J. Mater. Chem., 2005, 15, 749-753.

21 S. Hong, M. Y. Lee, A. O. Jackson and L. P. Lee, Light: Sci. Appl., 2015, 4, 267.

22 L. M. Bronstein, Small, 2011, 7, 1609-1618.

23 M. Brasch, R. M. Putri, M. V. de Ruiter, D. Luque, M. S. T. Koay, J. R. Castón and J. J. L. M. Cornelissen, J. Am. Chem. Soc., 2017, 139, 1512-1519.

24 A. Liu, L. Yang, C. H. H. Traulsen and J. J. L. M. Cornelissen, Chem. Commun., 2017, 53, 7632-7634.

25 L. Yang, A. Liu, S. Cao, R. M. Putri, P. Jonkheijm and J. J. L. M. Cornelissen, Chem.-Eur. J., 2016, 22, 15570-15582.

26 A. Liu, C. H. H. Traulsen and J. J. L. M. Cornelissen, ACS Catal., 2016, 6, 3084-3091.

27 F. Setaro, M. Brasch, U. Hahn, M. S. T. Koay, J. J. L. M. Cornelissen, A. de la Escosura and T. Torres, Nano Lett., 2015, 15, 1245-1251.

28 E. Jackson, M. Ferrari, C. Cuestas-Ayllon, R. FernándezPacheco, J. Perez-Carvajal, J. M. de la Fuente, V. Grazú and L. Betancor, Langmuir, 2015, 31, 3687-3695.

29 E. Ravera, T. Martelli, Y. Geiger, M. Fragai, G. Goobes and C. Luchinat, Coord. Chem. Rev., 2016, 15, 110-122.

30 D. Ma, M. Li, A. J. Patil and S. Mann, Adv. Mater., 2004, 16, 1838-1841.

31 S. Kerkhofs, F. Leroux, L. Allouche, R. Mellaerts, J. Jammaer, A. Aerts, C. E. A. Kirschhock, P. C. M. M. Magusin, 
F. Taulelle, S. Bals, G. Van Tendeloo and J. A. Martens, $R S C$ Adv., 2014, 4, 25650-25657.

32 Z. Liu, X. Xu and R. Tang, Adv. Funct. Mater., 2016, 26, 18621880.

33 S. Heinemann, T. Coradin and M. F. Desimone, Biomater. Sci., 2013, 1, 688-702.

34 M. L. Foglia, D. E. Camporotondi, G. S. Alvarez, S. Heinemann, T. Hanke, C. J. Perez, L. E. Diaz and M. F. Desimone, J. Mater. Chem. B, 2013, 1, 6283-6290.

35 G. Navarro-Tovar, G. Palestino and S. Rosales-Mendoza, Expert Rev. Vaccines, 2016, 5, 1449-1462.

36 W. K. Cho and S. H. Yang, Eur. J. Inorg. Chem., 2015, 2015, 4481-4494.

37 J. Lee, J. Choi, J. H. Park, M.-H. Kim, D. Hong, H. Cho, S. H. Yang and I. S. Choi, Angew. Chem., Int. Ed., 2014, 53, 8056-8059.

38 D. Arcos and M. Vallet-Regí, Acta Biomater., 2010, 6, 28742888.

39 S. Wang, X. Wang, F. G. Draenert, O. Albert, H. C. Schröder, V. Mailänder, G. Mitov and W. E. G. Müller, Bone, 2014, 67, 292-304.

40 M. T. Klem, M. Young and T. Douglas, J. Mater. Chem., 2008, 18, 3821-3823.

41 C. Jolley, M. Klem, R. Harrington, J. Parise and T. Douglas, Nanoscale, 2011, 3, 1004-1007.

42 K. Kumar, S. Kumar Doddi, M. Kalle Arunasree and P. Paik, Dalton Trans., 2015, 44, 4308-4317.

43 N. F. Steinmetz, S. N. Shah, J. E. Barclay, G. Rallapalli, G. P. Lomonossoff and D. J. Evans, Small, 2009, 5, 813-816.

44 E. S. Royston, A. D. Brown, M. T. Harris and J. N. Culver, J. Colloid Interface Sci., 2009, 332, 402-407.

45 E. Royston, S.-Y. Lee, J. N. Culver and M. T. Harris, J. Colloid Interface Sci., 2006, 298, 706-712.

46 B. Liu, Y. Cao, Z. Huang, Y. Duan and S. Che, Adv. Mater., 2015, 27, 479-497.

47 C. E. Fowler, W. Shenton, G. Stubbs and S. Mann, Adv. Mater., 2001, 13, 1266-1269.

48 K. Altintoprak, A. Seidenstücker, A. Welle, S. Eiben, P. Atanasova, N. Stitz, A. Plettl, J. Bill, H. Gliemann, H. Jeske, D. Rothenstein, F. Geiger and C. Wege, Beilstein J. Nanotechnol., 2015, 6, 1399-1412.

49 G. Wang, H.-J. Wang, H. Zhou, Q.-G. Nian, Z. Song, Y.-Q. Deng, X. Wang, S.-Y. Zhu, X.-F. Li, C.-F. Qin and R. Tang, ACS Nano, 2015, 9, 799-808.

50 Z. Niu, S. Kabisatpathy, J. He, L. A. Lee, J. Rong, L. Yang, G. Sikha, B. N. Popov, T. S. Emrick, T. P. Russell and Q. Wang, Nano Res., 2009, 2, 474-483.

51 G. Wang, H. Zhou, Q.-G. Nian, Y. Yang, C.-F. Qin and R. Tang, Chem. Sci., 2016, 7, 1753-1759.

52 R. Konecny, J. Trylska, F. Tama, D. Zhang, N. A. Baker, C. L. Brooks and J. A. McCammon, Biopolymers, 2006, 82, 106-120.

53 C. A. Hommersom, B. Matt, A. van der Ham, J. J. L. M. Cornelissen and N. Katsonis, Org. Biomol. Chem., 2014, 12, 4065-4069.

54 G. J. Bedwell, Z. Zhou, M. Uchida, T. Douglas, A. Gupta and P. E. Prevelige, Biomacromolecules, 2015, 16, 214-218.
55 P. A. Suci, M. T. Klem, T. Douglas and M. Young, Langmuir, 2005, 21, 8686-8693.

56 B. Michen and T. Graule, J. Appl. Microbiol., 2010, 109, 388397.

57 C. C. M. C. Carcouët, M. W. P. van de Put, B. Mezari, P. C. M. M. Magusin, J. Laven, P. H. H. Bomans, H. Friedrich, A. C. C. Esteves, N. A. J. M. Sommerdijk, R. A. T. M. van Benthem and G. de With, Nano Lett., 2014, 14, 1433-1438.

58 P. W. J. G. Wijnen, T. P. M. Beelen, C. P. J. Rummens and R. A. van Santen, J. Non-Cryst. Solids, 1991, 136, 119125.

59 K. W. Adolph, J. Gen. Virol., 1975, 28, 137-145.

60 J. A. Speir, S. Munshi, G. Wang, T. S. Baker and J. E. Johnson, Structure, 1995, 3, 63-78.

61 T. Douglas, E. Strable, D. Willits, A. Aitouchen, M. Libera and M. Young, Adv. Mater., 2002, 14, 415-418.

62 T. Douglas and M. Young, Nature, 1998, 393, 152-155.

63 T. Douglas and M. Young, Science, 2006, 312, 873-875.

64 L. Lavelle, J.-P. Michel and M. Gingery, J. Virol. Methods, 2007, 146, 311-316.

65 K. W. Adolph, Eur. J. Biochem., 1975, 53, 449-455.

66 J. Chen, R. Zhang, L. Han, B. Tu and D. Zhao, Nano Res., 2013, 6, 871-879.

67 R. F. Bruinsma, M. Comas-Garcia, R. F. Garmann and A. Y. Grosberg, Phys. Rev. E, 2016, 93, 032405.

68 A. Liu, M. Verwegen, M. V. de Ruiter, S. J. Maassen, C. H. H. Traulsen and J. J. L. M. Cornelissen, J. Phys. Chem. $B, 2016,120,6352-6357$.

69 H. I. Oh, J. E. Hoff, G. S. Armstrong and L. A. Haff, J. Agric. Food Chem., 1980, 28, 394-398.

70 J. P. Van Buren and W. B. Robinson, J. Agric. Food Chem., 1969, 17, 772-777.

71 J. Gao, H. Lei, Z. Han, Q. Shi, Y. Chen and Y. Jiang, Sci. Rep., 2017, 7, 45215.

72 Z. Gao and I. Zharov, Chem. Mater., 2014, 26, 2030-2037.

73 Y. Chen, H. Chen, Y. Sun, Y. Zheng, D. Zeng, F. Li, S. Zhang, X. Wang, K. Zhang, M. Ma, Q. He, L. Zhang and J. Shi, Angew. Chem., 2011, 123, 12713-12717.

74 M. Colombo, S. Carregal-Romero, M. F. Casula, L. Gutierrez, M. P. Morales, I. B. Bohm, J. T. Heverhagen, D. Prosperi and W. J. Parak, Chem. Soc. Rev., 2012, 41, 4306-4334.

75 J. G. Croissant, D. Zhang, S. Alsaiari, J. Lu, L. Deng, F. Tamanoi, A. M. AlMalik, J. I. Zink and N. M. Khashab, J. Controlled Release, 2016, 229, 183-191.

76 R. Ciganda, N. Li, C. Deraedt, S. Gatard, P. Zhao, L. Salmon, R. Hernandez, J. Ruiz and D. Astruc, Chem. Commun., 2014, 50, 10126-10129.

77 K. Kuroda, T. Ishida and M. Haruta, J. Mol. Catal. A: Chem., 2009, 298, 7-11.

78 R. M. Putri, J. J. L. M. Cornelissen and M. S. T. Koay, ChemPhysChem, 2015, 16, 911-918.

79 M. Brasch, A. de la Escosura, Y. Ma, C. Uetrecht, A. J. R. Heck, T. Torres and J. J. L. M. Cornelissen, J. Am. Chem. Soc., 2011, 133, 6878-6881.

80 A. de la Escosura, M. Verwegen, F. D. Sikkema, M. ComellasAragones, A. Kirilyuk, T. Rasing, R. J. M. Nolte and J. J. L. M. Cornelissen, Chem. Commun., 2008, 1542-1544. 